\title{
Mechanism of oxidative damage to DNA by Fe-loaded MCM-41 irradiated with visible light
}

\author{
WANG XiaoXing, GU Yan, FANG YanFen \& HUANG YingPing* \\ Engineering Research Center of Eco-environment in Three Gorges Reservoir Region, Ministry of Education, China Three Gorges University, \\ Yichang 443002, China
}

Received September 26, 2011; accepted November 17, 2011; publishe online March 12, 2012

\begin{abstract}
The mechanism of oxidative damage to deoxyribonucleic acid (DNA) by iron-containing mesoporous molecular sieves (MCM-41) irradiated with visible light was elucidated. Fe-loaded MCM-41 (Fe/MCM-41) was used as a photocatalyst and the damage to calf thymus DNA caused by hydrogen peroxide $\left(\mathrm{H}_{2} \mathrm{O}_{2}\right)$ was studied. The damage and extent of oxidation of DNA were measured by high-performance liquid chromatography (HPLC) and intermediate products were detected by HPLC/electrospray ionization tandem mass spectrometry. Electron spin resonance was used to detect changes in reactive oxygen species and peroxidase catalytic spectrophotometry was used to determine the concentration of $\mathrm{H}_{2} \mathrm{O}_{2}$. The results indicated that Fe/MCM-41 efficiently activated $\mathrm{H}_{2} \mathrm{O}_{2}$ in solution at $\mathrm{pH}$ 4.0-8.0 under irradiation with visible light. The photocatalytic system degraded DNA most effectively at $\mathrm{pH}$ 5.0-6.0 but also operated at $\mathrm{pH}$ 8.0. At $\mathrm{pH} 4.2$, the degree of DNA damage reached $25.65 \%$ after $5 \mathrm{~h}$ and the kinetic constant was $5.89 \times 10^{-2} \mathrm{~min}^{-1}$. Damage to DNA was predominantly caused by hydroxyl radicals generated in the system. The mechanism of DNA damage is of potential concern to human health because it can occur in neutral solutions irradiated by visible light.
\end{abstract}

Fe/MCM-41, DNA, oxidative damage, photocatalysis, mechanism

Citation: Wang X X, Gu Y, Fang Y F, et al. Mechanism of oxidative damage to DNA by Fe-loaded MCM-41 irradiated with visible light. Chin Sci Bull, 2012, 57: 1504-1509, doi: 10.1007/s11434-012-5042-1

Damage to deoxyribonucleic acid (DNA) caused by physical and chemical agents can produce cancers and is also implicated in the aging process [1]. Highly oxidizing species and UV radiation $(\lambda<380 \mathrm{~nm})$ produce free radicals that attack nucleic acids [2]. For example, it is known that hydroxyl radicals $(\cdot \mathrm{OH})$ produced by titanium oxide $\left(\mathrm{TiO}_{2}\right)$ irradiated with UV light damage DNA [3]. Iron-based substances are widely distributed in almost all organisms. Iron is a component of hemoglobin, myoglobin, cytochrome oxidase and many metallic enzymes, including catalase. Iron catalase decomposes hydrogen peroxide $\left(\mathrm{H}_{2} \mathrm{O}_{2}\right)$ produced by oxidation processes, including metabolism. However, iron-based compounds also produce $\cdot \mathrm{OH}$, superoxide radicals $\left(\mathrm{O}_{2}^{-}\right)$and other oxygen species that cause non-selective DNA damage when irradiated with sunlight $(3 \%-5 \%$ UV) or visible light $(\lambda>450 \mathrm{~nm})$ [4]. The well-known

*Corresponding author (email: chem_ctgu@126.com)
Fenton reaction is effective only at $\mathrm{pH} \leqslant 3.0$ [5]. However, iron-loaded mesoporous molecular sieves (Fe/MCM-41) display good photocatalytic activity under neutral conditions and irradiation with visible light, yielding $\mathrm{H}_{2} \mathrm{O}_{2}$ [4]. As a result, it is important to understand the mechanism of damage to DNA induced by Fe/MCM-41.

In this investigation, photocatalytic damage caused by activation of $\mathrm{H}_{2} \mathrm{O}_{2}$ by Fe/MCM-41 at $\mathrm{pH} 4.2$ under irradiation with visible light $(\lambda>450 \mathrm{~nm})$ using calf thymus DNA was studied. Fe/MCM-41 degrades DNA most effectively at $\mathrm{pH}$ 5.0-6.0, and was still effective at $\mathrm{pH}$ 8.0, which was the highest $\mathrm{pH}$ tested. The degree of oxidation and damage to DNA was detected by high-performance liquid chromatography (HPLC). HPLC/electrospray ionization tandem mass spectrometry (HPLC-ESI-MS/MS) was used to analyze the products in damaged DNA using 8-hydroxy-2'-deoxyguanosine $(8-\mathrm{OHdG})$ as an internal standard. Electron spin resonance (ESR) was used to determine the change in reactive 
oxygen species, and peroxidase (POD) catalytic spectrophotometry was used to determine the concentration of $\mathrm{H}_{2} \mathrm{O}_{2}$ in the reaction mixture.

\section{Experimental}

\subsection{Materials}

Calf thymus DNA (10.0 mg/L), 8-OHdG (10.0 mg/L), 5,5dimethyl-1-pyrroline-N-oxide (DMPO) $(0.4 \mathrm{~mol} / \mathrm{L})$, horseradish POD $(1.0 \mathrm{mg} / \mathrm{mL})$, and $N, N$-diethyl- $p$-phenylenediamine (DPD) $(10.0 \mathrm{mg} / \mathrm{mL})$ were purchased from SigmaAldrich Co. Methanol was obtained from J. T. Baker Co. Hexadecyl trimethyl ammonium bromide (CTAB) was obtained from Tianjin Bodi Chemical Holding Co. Tetraethyl orthosilicate (TEOS) was purchased from Tianjin Kermel Chemical Reagent Co. The initial concentration of $\mathrm{H}_{2} \mathrm{O}_{2}$ was $7.49 \times 10^{-2} \mathrm{~mol} / \mathrm{L}$. All reagents were of analytical grade and used without further purification. Double distilled water was used in all experiments.

\subsection{Preparation and characterization of the photo- catalyst}

MCM-41 sieves were prepared by the hydrothermal method. Fe/MCM-41 was prepared by wet impregnation with specific concentrations of $\mathrm{Fe}^{2+}$ solution [6]. CTAB (1.0 g) and $\mathrm{FeSO}_{4}\left(3.8 \times 10^{-4} \mathrm{~g}\right)$ were dissolved in water $(25.0 \mathrm{~mL})$. The optimal $\mathrm{FeSO}_{4} / \mathrm{CTAB}$ molar ratio was $1: 20$, and the $\mathrm{pH}$ of the solutions was adjusted to 4.0 with acetic acid. The solution was held at $30^{\circ} \mathrm{C}$ and stirred at $300 \mathrm{r} / \mathrm{min}$ for $20 \mathrm{~h}$. TEOS $(5.0 \mathrm{~mL})$ was added dropwise and stirring was continued for $4-5 \mathrm{~h}$. The resulting solution was added to the reaction vessel and then heated at $100^{\circ} \mathrm{C}$ for $24 \mathrm{~h}$. Finally, the samples were washed until neutral, dried at $110^{\circ} \mathrm{C}$ for $6 \mathrm{~h}$ in an oven and then calcined at $500^{\circ} \mathrm{C}$ for $4 \mathrm{~h}$ in a muffle furnace. The catalyst was characterized by atomic absorption spectrophotometry (AAS, Varian, USA) and UV-Vis spectrophotometry (Perkin Elmer, USA).

\subsection{Experimental procedure}

A cylindrical photoreactor $(30.0 \mathrm{~mL})$ with a $500 \mathrm{~W}$ halogen lamp (Institute of Electric Light Sources, Guangzhou, China) as the light source was used. The source was positioned inside the cylindrical Pyrex vessel surrounded by a jacket with circulating water to cool the lamp. A cutoff filter (diameter $3 \mathrm{~cm}$ ) was used to remove wavelengths less than $420 \mathrm{~nm}$ ensuring that irradiation was only of visible light $(\lambda>420 \mathrm{~nm})$. The distance between the reaction vessel and light source was $10 \mathrm{~cm}$.

Standard solutions of calf thymus DNA and $8-\mathrm{OHdG}$ $(10 \mathrm{mg} / \mathrm{L})$ were prepared by addition of solid DNA or 8-OHdG $(1.0 \mathrm{mg})$ to Milli-Q water $(100.0 \mathrm{~mL})$. Calf thymus DNA (10 mL, $10 \mathrm{mg} / \mathrm{L})$ and Fe/MCM-41 (5.0 mg) were placed in the cylindrical reaction vessel. To achieve an adsorption-desorption equilibrium between the substrate and photocatalyst, the dispersion was stirred for $60 \mathrm{~min}$ in the dark before beginning irradiation. $\mathrm{H}_{2} \mathrm{O}_{2}\left(0.5 \mathrm{~mL}, 7.49 \times 10^{-4}\right.$ $\mathrm{mol} / \mathrm{L}$ ) was added to the reaction mixture, the $\mathrm{pH}$ of the dispersion was adjusted to 4.2 with acetic acid, and then the vessel was irradiated with visible light. At appropriate time intervals, $1.0 \mathrm{~mL}$ aliquots of the reaction mixture were extracted and centrifuged to remove the Fe/MCM-41 particles before analysis. A series of aliquots under the following conditions were collected to act as controls: dark/Fe/MCM$41 / \mathrm{H}_{2} \mathrm{O}_{2}$, vis/Fe/MCM-41 and vis/ $\mathrm{H}_{2} \mathrm{O}_{2}$.

HPLC analysis with UV detection was used to accurately determine the degree of DNA damage [7,8]. The $1.0 \mathrm{~mL}$ aliquots of the reaction mixture were placed in centrifuge tubes $(1.5 \mathrm{~mL})$. After centrifugation for $15 \mathrm{~min}$ at $15000 \mathrm{r} / \mathrm{min}$, the supernatant was analyzed immediately on a HPLC (Waters, USA) containing a Kromasil $\mathrm{C}_{18}$ column $(4.6 \times 200 \mathrm{~mm}, 5 \mu \mathrm{m}$ particle size). The mobile phase was methanol and buffer solution $(25: 75, \mathrm{v}: \mathrm{v})$. The buffer solution contained citric acid $(0.03 \mathrm{mmol} / \mathrm{L})$, acetic acid $(0.02 \mathrm{mmol} / \mathrm{L})$, sodium acetate $(0.05 \mathrm{mmol} / \mathrm{L})$, and sodium hydroxide $(0.05 \mathrm{mmol} / \mathrm{L})$ in Milli-Q water. The flow rate was maintained at $0.4 \mathrm{~mL} / \mathrm{min}$, the injection volume was $20 \mu \mathrm{L}$ and the detection wavelength was $258 \mathrm{~nm}$. The temperature of the column was set at $25^{\circ} \mathrm{C}$.

HPLC-ESI-MS/MS was used to detect the products of DNA damage [9]. The separation was performed isocratically with a mobile phase of ammonium formate $(5 \mathrm{mmol} / \mathrm{L})$ and methanol $(78: 22, \mathrm{v}: \mathrm{v})$. The samples were concentrated on a $\mathrm{C}_{18}$ solid phase extraction column with a $1100 \mathrm{LC} /$ MSD Trap (Agilent, USA). Positive ions were analyzed using ESI and MS data were acquired in full-scan mode (50-800 Dalton). An extracted ion chromatogram (EIC) was also obtained from the MS detector signal. Ion source parameters were as follows: the nebulizer pressure was 40.0 psi, the potential of the capillary exit was $138.6 \mathrm{~V}$, the flow rate was $10.00 \mathrm{~L} / \mathrm{min}$, the capillary temperature was $350^{\circ} \mathrm{C}$, the ESI voltage was $3.5 \mathrm{kV}$ at a temperature of $325^{\circ} \mathrm{C}$, the temperature of the ion source was $120^{\circ} \mathrm{C}$, the ion energy was $1.0 \mathrm{~V}$, and the cone potential was $40.0 \mathrm{~V}$. 8-OHdG was used as an internal standard.

The formation of $\cdot \mathrm{OH}$ was determined using ESR (Bruker, Germany) at room temperature $\left(25^{\circ} \mathrm{C}\right)$ with DMPO as the spin-trapping reagent [10]. The light source was a ND:YAG pulsed laser ( $\lambda=532 \mathrm{~nm}, 10 \mathrm{~Hz}$, Quanta-Ray). Detection conditions were as follows: center field of $3486.7 \mathrm{G}$, sweep width of $100.0 \mathrm{G}$, microwave frequency of $100 \mathrm{kHz}$ and power of $10.02 \mathrm{~mW}$. The content of $\mathrm{H}_{2} \mathrm{O}_{2}$ was determined by the POD catalytic method $[11,12]$.

\section{Results}

\subsection{Photochemical characteristics of Fe/MCM-41}

Figure 1 shows the UV-Vis diffuse reflectance spectra of 


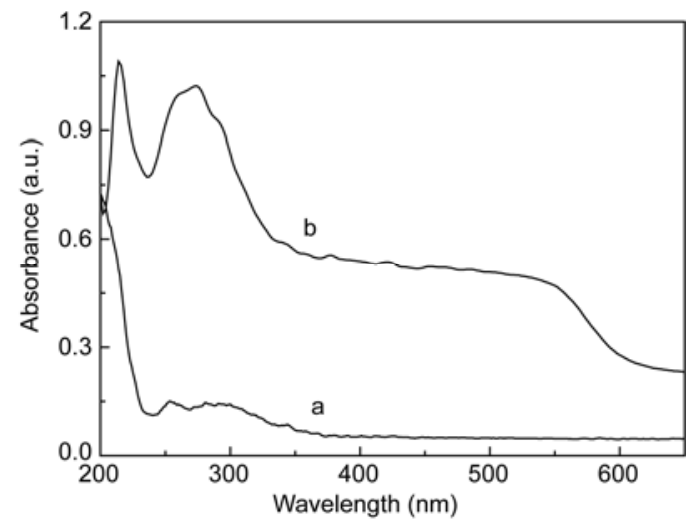

Figure 1 UV-Vis diffuse reflectance spectra of MCM-41 (a) and $\mathrm{Fe} /$ MCM-41(b).

MCM-41 (curve a) and Fe/MCM-41 (curve b). MCM-41 displays very low absorbance at $350-650 \mathrm{~nm}$ while the Fe/MCM-41 absorbs strongly with an absorption peak at $274 \mathrm{~nm}$. The increased absorbance from 400-600 nm indicates a broadened response range to visible light caused by the presence of $\mathrm{Fe}$, which should increase the photocatalytic activity of Fe/MCM-41 under visible light.

\subsection{DNA damage assays}

In the following section, the extent of oxidative damage to DNA caused by the Fe/MCM-41 photocatalytic system is evaluated. The optimal level of Fe/MCM-41 (0.5 g/L) was used with an initial DNA concentration of $10 \mathrm{mg} / \mathrm{L}$, an initial $\mathrm{H}_{2} \mathrm{O}_{2}$ concentration of $7.49 \times 10^{-4} \mathrm{~mol} / \mathrm{L}$, and an initial $\mathrm{pH}$ of 4.2 .

Chromatograms showing DNA damage after 0, 4, 6, 8 and $10 \mathrm{~h}$ are presented from top to bottom in Figure 2. Under the conditions described in the previous section, the DNA peaks eluted at about $3.5 \mathrm{~min}$, followed by peaks from decomposition products and the $8-\mathrm{OHdG}$ internal standard peak at $9.5 \mathrm{~min}$. The product causing the relatively large peak at 5.5 min was unknown. The intensity of the DNA peak decreased with reaction time while the intensities of the peaks from degradation products increased. The increased retention time of the products indicated that species formed by oxidative damage to DNA were more polar than DNA, as would be expected. The results also indicated that 8-OHdG was a product of DNA damage.

Kinetic curves for DNA damage were obtained from analysis of the HPLC data. Figure 3 shows the DNA peak area, $S$, as a function of reaction time. There was no oxidative damage to DNA when $\mathrm{H}_{2} \mathrm{O}_{2}$ was absent under visible irradiation (curve a). The extent of DNA damage was small when the catalyst was absent (curve b) or when the reaction was run in the dark (curve c) and exhibited kinetic constants, $k$, of $1.41 \times 10^{-2}$ and $1.77 \times 10^{-2} \mathrm{~min}^{-1}$, respectively. However, when the reaction was run in the presence of both $\mathrm{H}_{2} \mathrm{O}_{2}$ and Fe/MCM-41 under visible irradiation (curve d), the degree

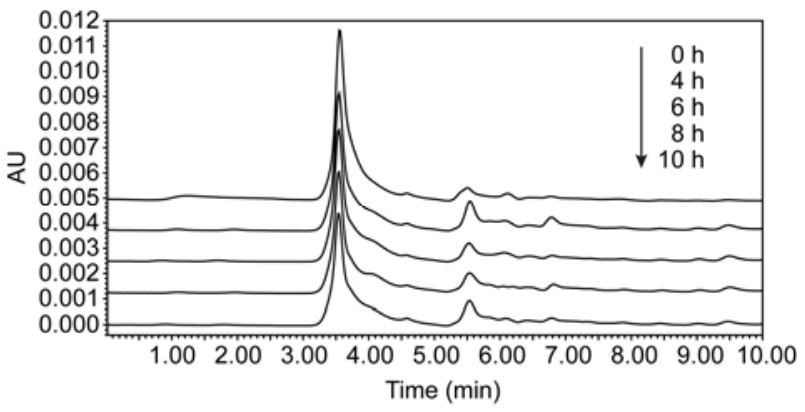

Figure 2 HPLC chromatograms showing the damage to DNA caused by vis/Fe/MCM-41/ $\mathrm{H}_{2} \mathrm{O}_{2}$. Reaction conditions: DNA $10.0 \mathrm{mg} / \mathrm{L}, \mathrm{pH} 4.2, \mathrm{Fe} /$ MCM-41 $0.5 \mathrm{~g} / \mathrm{L}, \mathrm{H}_{2} \mathrm{O}_{2} 7.49 \times 10^{-4} \mathrm{~mol} / \mathrm{L}$.

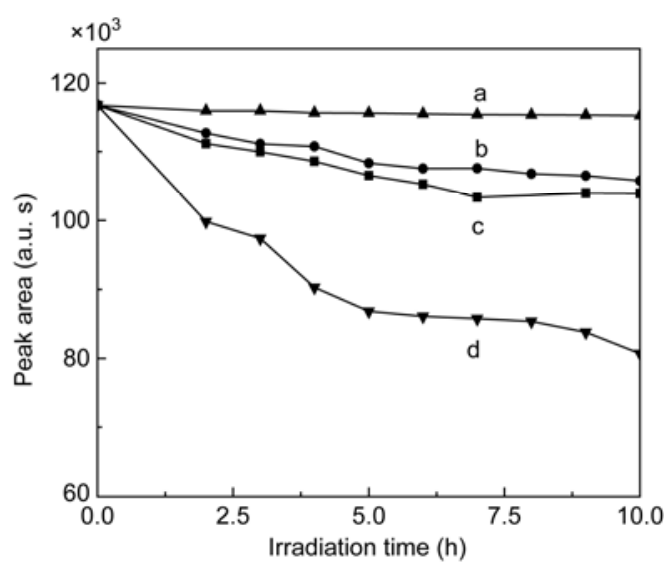

Figure 3 Kinetic curves for damage to DNA under various reaction conditions: (a) without $\mathrm{H}_{2} \mathrm{O}_{2}$, (b) without Fe/MCM-41, (c) in the dark, and (d) full catalytic system. Conditions: DNA $10.0 \mathrm{mg} / \mathrm{L}, \mathrm{pH} 4.2, \mathrm{Fe} / \mathrm{MCM}-41$ $0.5 \mathrm{~g} / \mathrm{L}, \mathrm{H}_{2} \mathrm{O}_{2} 7.49 \times 10^{-4} \mathrm{~mol} / \mathrm{L}$.

of oxidative damage to DNA increased dramatically. The extent of DNA damage was $25.65 \%$ after $5 \mathrm{~h}$ and $k$ was $5.89 \times 10^{-2} \mathrm{~min}^{-1}$. The results clearly indicate that damage to DNA caused by $\mathrm{H}_{2} \mathrm{O}_{2}$ was greatly enhanced by the photocatalytic action of Fe/MCM-41.

\subsection{HPLC-ESI-MS/MS identification of intermediates produced by damage to DNA}

To elucidate possible mechanisms of oxidative damage to DNA, HPLC-ESI-MS/MS was used to identify the reaction intermediates produced during photocatalytic degradation of DNA.

Figure 4(a) and (b) show HPLC chromatograms of the reaction mixture after 0 and $8 \mathrm{~h}$ of irradiation, respectively. Figure 4(c) and (d) show an EIC and mass chromatogram after $8 \mathrm{~h}$ of irradiation. Compared to the initial results (Figure 4(a)), the intensity of the DNA peak decreased after irradiation for $8 \mathrm{~h}$ (Figure 4(b)) and peaks from damage products appeared at a retention time of $10.7 \mathrm{~min}$. Oxidative damage to DNA is indicated by the peaks in the EIC of the degradation products (retention time of $\sim 10.7 \mathrm{~min}$ ) displayed 

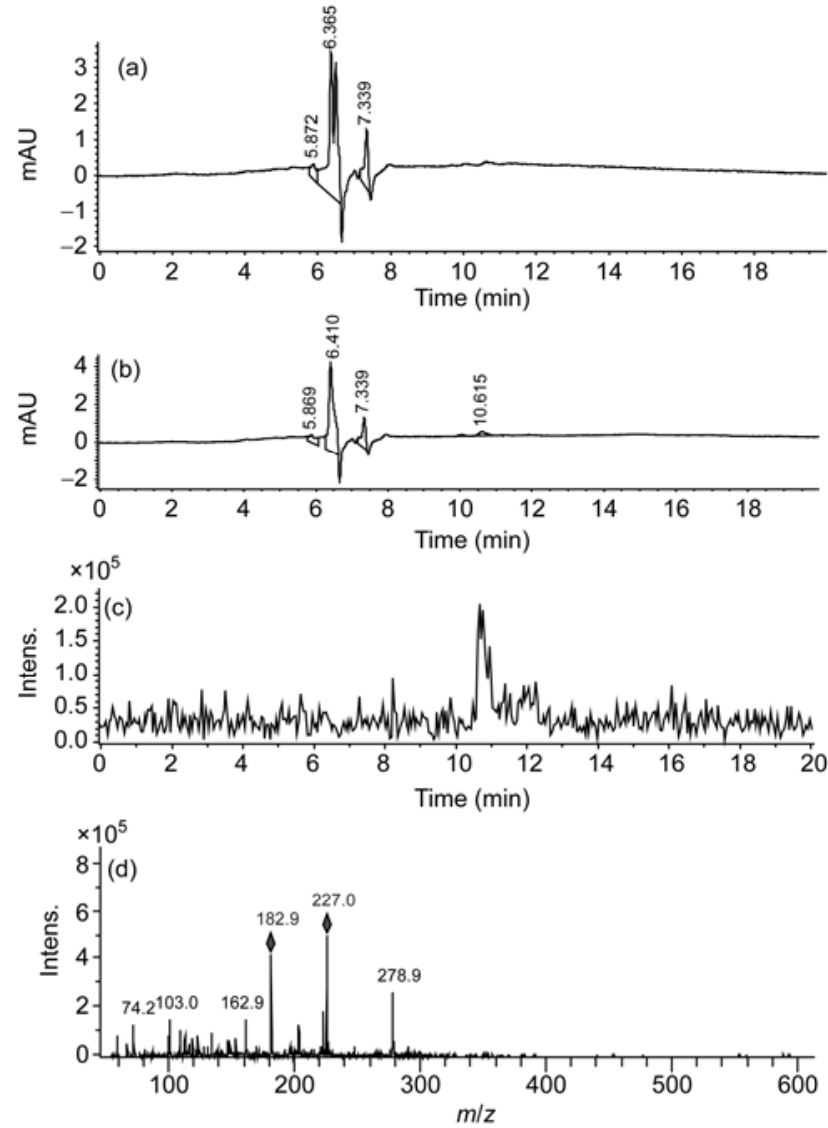

Figure 4 Chromatograms of the reaction mixture after of (a) $0 \mathrm{~h}$ and (b) $8 \mathrm{~h}$, and (c) EIC scan, and (d) MS scan after $8 \mathrm{~h}$ of reaction. Reaction conditions: DNA $10.0 \mathrm{mg} / \mathrm{L}, \mathrm{pH} 4.2$, Fe/MCM-41 $0.5 \mathrm{~g} / \mathrm{L}, \mathrm{H}_{2} \mathrm{O}_{2} 7.49 \times 10^{-4} \mathrm{~mol} / \mathrm{L}$.

in Figure 4(c). Figure 4(d) reveals a fragment with $m / z$ 278.9. The peaks are similar to those produced by the $8-\mathrm{OHdG}$ internal standard and are consistent with isomers of 8OHdG. On the basis of the experimental results and literature reports [13], the fragment peak with $m / z 278.9$ ( $\mathrm{M}$ 278) is from 8-oxo-7, 8-dihydro-2'-deoxyguanosine (8-oxodG), an intermediate commonly produced during oxidative damage of DNA.

\subsection{Decomposition of $\mathrm{H}_{2} \mathrm{O}_{2}$ in the $\mathrm{Fe} / \mathrm{MCM}-41 / \mathrm{H}_{2} \mathrm{O}_{2}$ system}

Changes in the concentration of $\mathrm{H}_{2} \mathrm{O}_{2}$ during the photocatalytic degradation of DNA are displayed in Figure 5. Curve a shows that no change in the concentration of $\mathrm{H}_{2} \mathrm{O}_{2}$ was observed when it was not added to the reaction mixture. Rapid $\mathrm{H}_{2} \mathrm{O}_{2}$ activation was observed in the full catalytic system (curve b) and $\mathrm{H}_{2} \mathrm{O}_{2}$ was fully consumed after $9 \mathrm{~h}$. The consumption rate of $\mathrm{H}_{2} \mathrm{O}_{2}$ decreases in the absence of light (curve c) or catalyst (curve d).

These results indicate that $\mathrm{Fe} / \mathrm{MCM}-41$ in the presence of light efficiently activates $\mathrm{H}_{2} \mathrm{O}_{2}$. $\cdot \mathrm{OH}$ produced by transformation of $\mathrm{H}_{2} \mathrm{O}_{2}$ in the photocatalytic reaction attacks DNA groups leading to DNA damage [14]. DNA damage is

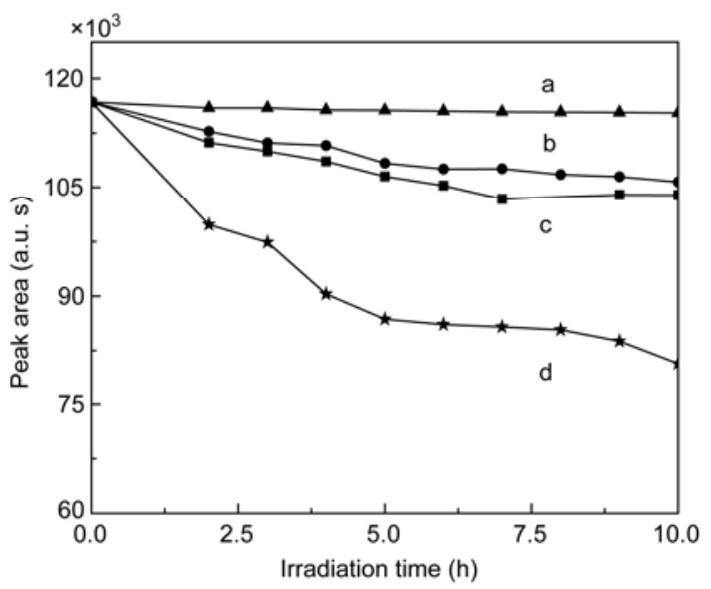

Figure 5 Decomposition of $\mathrm{H}_{2} \mathrm{O}_{2}$ under various reaction conditions. Curve a, without $\mathrm{H}_{2} \mathrm{O}_{2}$; b, full catalytic system; c, in the dark; d, without Fe/MCM-41. Reaction conditions: DNA $10.0 \mathrm{mg} / \mathrm{L}$, pH 4.2, Fe/MCM-41 $0.5 \mathrm{~g} / \mathrm{L}, \mathrm{H}_{2} \mathrm{O}_{2} 7.49 \times 10^{-4} \mathrm{~mol} / \mathrm{L}$.

predominantly caused by $\cdot \mathrm{OH}$ generated by the catalytic system, as discussed below.

\subsection{Analysis and determination of active oxygen species}

To verify that $\cdot \mathrm{OH}$ is involved in the vis/Fe/MCM- $41 / \mathrm{H}_{2} \mathrm{O}_{2}$ system, the active oxygen species was determined. The formation of $\cdot \mathrm{OH}$ was examined in the system under visible light irradiation by ESR (as described in Section 1.3), which is a useful tool for detecting short-lived radicals. The ESR signals of the DMPO- $\cdot \mathrm{OH}$ adducts detected in the system are presented in Figure 6.

No ESR signals were observed when the reaction was performed in the dark. Under visible irradiation, the characteristic quartet of peaks from DMPO- $\cdot \mathrm{OH}$ appeared gradually in the system after $92 \mathrm{~s}$. This indicates that the photocatalytic reaction primarily involves the generation and reaction of $\cdot \mathrm{OH}$. Therefore, the primary active oxygen species damaging DNA in the vis/Fe/MCM- $41 / \mathrm{H}_{2} \mathrm{O}_{2}$ system is $\cdot \mathrm{OH}$.

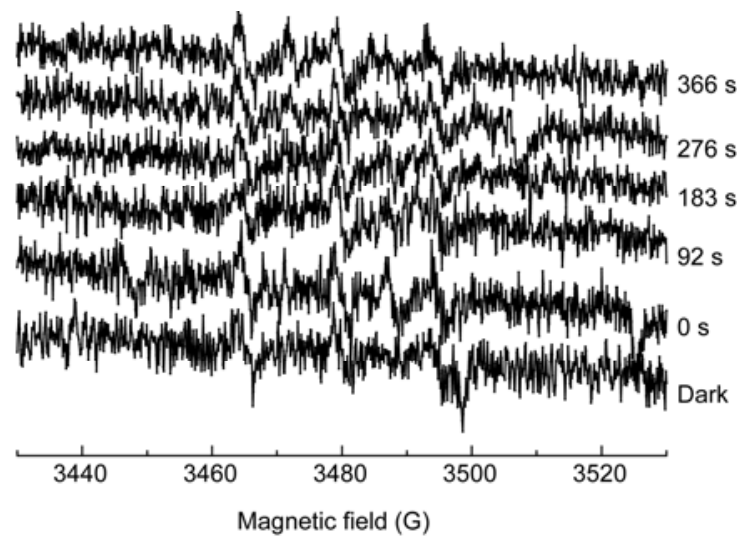

Figure 6 ESR signals of the DMPO- $\cdot \mathrm{OH}$ adducts. Reaction conditions: DNA 10.0 mg/L, pH 4.2, Fe/MCM-41 0.5 g/L, $\mathrm{H}_{2} \mathrm{O}_{2} 7.49 \times 10^{-4} \mathrm{~mol} / \mathrm{L}$. 


\subsection{Effect of pH on DNA damage}

$\mathrm{pH}$ has a large effect on the Fenton system (vis/ $\left./ \mathrm{Fe}^{2+} / \mathrm{H}_{2} \mathrm{O}_{2}\right)$, in which $\mathrm{Fe}^{2+}$ efficiently activates $\mathrm{H}_{2} \mathrm{O}_{2}$ and maximizes the formation of free radicals at $\mathrm{pH} \leqslant 3.0[5,14]$. To characterize the effect of $\mathrm{pH}$ on the damage to DNA in the current system, the degree of damage to DNA caused by vis $/ \mathrm{Fe}^{2+} / \mathrm{H}_{2} \mathrm{O}_{2}$ and vis/Fe/MCM- $41 / \mathrm{H}_{2} \mathrm{O}_{2}$ at various $\mathrm{pH}$ was measured after $4 \mathrm{~h}$ of irradiation.

Figure 7 shows that the degree of DNA damage was $100 \%$ at $\mathrm{pH} 3.0$ even in the absence of $\mathrm{H}_{2} \mathrm{O}_{2}$, catalyst or light irradiation. In this case, damage was caused by hydrolysis under acidic conditions $(\mathrm{pH}$ 3.0) rather than by $\cdot \mathrm{OH}$. Compared with $\mathrm{Fe}^{2+}$, Fe/MCM-41 displays better catalytic activity toward the damage of DNA at $\mathrm{pH} \sim 4.0-8.0$. Fe/MCM-41 photocatalysis damages DNA over a wide $\mathrm{pH}$ range from 4.0-8.0. The largest degradation rates after $4 \mathrm{~h}$ were found at $\mathrm{pH} 5.0$ and 6.0. Fe/MCM-41 also displays high catalytic activity at neutral $\mathrm{pH}$. This indicates that the molecular sieves act not only as a carrier of iron ions and substrate absorbent, but also provides a microenvironment with an active center that enhances activation of $\mathrm{H}_{2} \mathrm{O}_{2}$ over a broad range of $\mathrm{pH}$, including neutral conditions.

\subsection{Stability of Fe/MCM-41}

To investigate the stability Fe/MCM-41, the Fe/MCM-41/ $\mathrm{H}_{2} \mathrm{O}_{2}$ system was reused under visible light for five consecutive cycles (Figure 8). After each experiment, identical concentrations of DNA and $\mathrm{H}_{2} \mathrm{O}_{2}$ were added, and the $\mathrm{pH}$ was readjusted to the initial $\mathrm{pH}$. The final damage efficiency of DNA by vis/Fe/MCM- $41 / \mathrm{H}_{2} \mathrm{O}_{2}$ was $40.5 \%$. The concentration of Fe was determined by AAS. Initially, $32.42 \mathrm{mg}$ of Fe was present per gram of Fe/MCM-41. After the recycling experiment at $\mathrm{pH} 4.2$, the concentration of $\mathrm{Fe}$ was 17.66 $\mu \mathrm{g} / \mathrm{L}$, which indicated that $\mathrm{Fe} / \mathrm{MCM}-41$ was stable.

\section{Mechanism of DNA damage}

After visible irradiation, DNA was damaged by $\cdot \mathrm{OH}$ by the system vis/Fe/MCM- $41 / \mathrm{H}_{2} \mathrm{O}_{2}$. Figure 9 shows the proposed mechanism for the damage of DNA by Fe/MCM-41 under visible light irradiation. Guanine is the most susceptible DNA residue towards oxidation reactions mediated by $\cdot \mathrm{OH}$ [15]. The structures of reaction intermediates determined by HPLC-ESI-MS/MS analysis indicate that it is a change in the molecular structure of guanine that leads to oxidative damage of the DNA.

The reactive species that causes the damage is $\cdot \mathrm{OH}$, which is produced by activation of $\mathrm{H}_{2} \mathrm{O}_{2}$ by Fe/MCM-41 under visible light irradiation $(\lambda>450 \mathrm{~nm})$. The two main decomposition pathways of the guanine residues of DNA involving $\cdot \mathrm{OH}$ are at C-4 and C-8 (Figure 9) [13]. The progression of oxidative damage of DNA involves the following

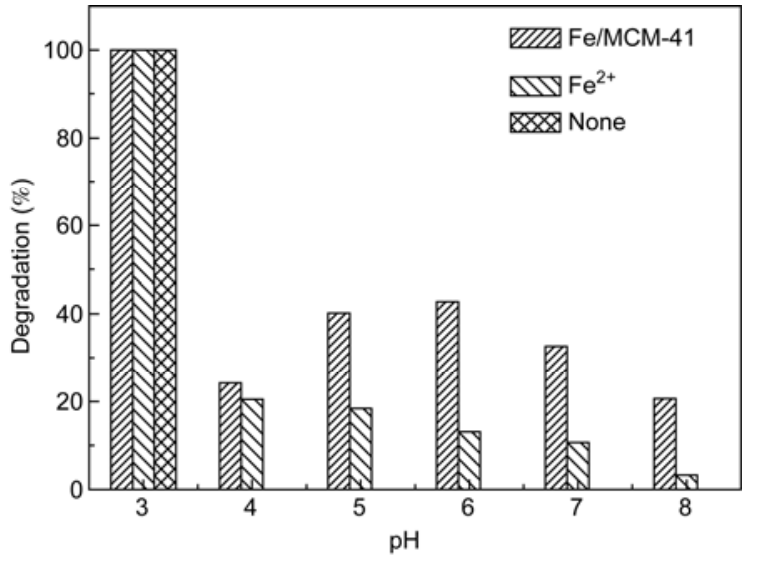

Figure 7 Effect of $\mathrm{pH}$ on damage to DNA. Reaction conditions: DNA $10.0 \mathrm{mg} / \mathrm{L}, \mathrm{Fe} / \mathrm{MCM}-410.5 \mathrm{~g} / \mathrm{L}, \mathrm{FeSO}_{4} 1.62 \times 10^{-2} \mathrm{~g} / \mathrm{L}, \mathrm{H}_{2} \mathrm{O}_{2} 7.49 \times 10^{-4} \mathrm{~mol} / \mathrm{L}$.

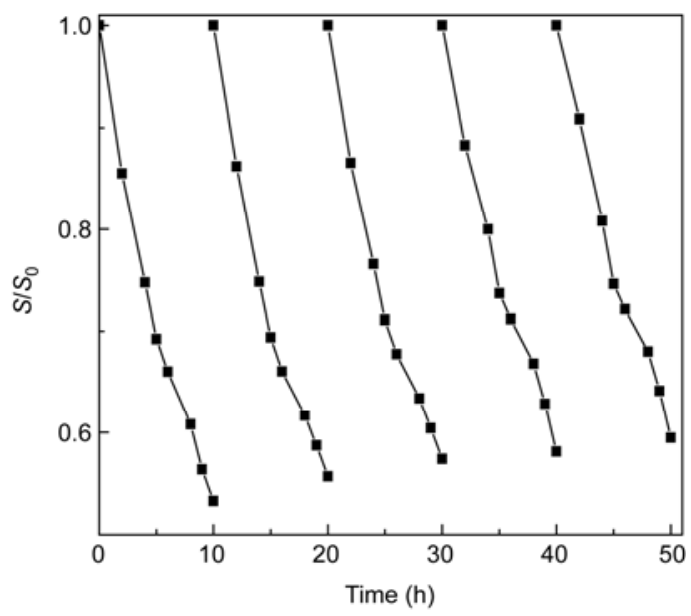

Figure 8 Five consecutive cycles of DNA damage. Reaction conditions: DNA $10.0 \mathrm{mg} / \mathrm{L}, \mathrm{pH} 4.2$, Fe/MCM-41 $0.5 \mathrm{~g} / \mathrm{L}, \mathrm{H}_{2} \mathrm{O}_{2} 7.49 \times 10^{-4} \mathrm{~mol} / \mathrm{L}$.

process. First, oxidation products (B and $\mathbf{C}$ in Figure 9) form by addition of $\cdot \mathrm{OH}$ at $\mathrm{C}-4$ of guanine (A in Figure 9). Then, the resulting radical $(\mathbf{B})$, dehydrates in neutral solution, yielding the uncharged oxidizing radical $(\mathbf{C})$. $\mathbf{C}$ combines with atmospheric oxygen to produce guanine (A in Figure 9). Second, the formation of an imidazole open-ring product, which is not observed in the $\cdot \mathrm{OH}$-mediated oxidation of guanine, suggests the presence of a competing reductive process involving the 8-hydroxy-7,8-dihydro-guanyl radical (8-OHdG, D in Figure 9), the precursor to 8-oxodG (E in Figure 9) $[16,17]$. From analysis of the HPLC-ESIMS/MS spectrum, 8-oxodG $(\mathrm{m} / \mathrm{z} 278.9$ or M 278, Figure 4, D) was one of the products of DNA damage. Finally, 8-oxodG is mineralized to $\mathrm{CO}_{2}, \mathrm{NH}_{3}$ and other organic acids. Some damage to DNA can be repaired through a series of reactions, but most is irreparable. The main decomposition product of the guanine moiety is 8 -oxodG $(\sim 50 \%)$ [18]. 8-OxodG may be considered as a ubiquitous marker of oxidative stress because it is efficiently produced by $\cdot \mathrm{OH}[18]$. 
<smiles>[R7]n1cnc2c(O)nc(N)nc21</smiles>

Figure 9 Mechanism of oxidative damage of DNA by Fe/MCM-41 under visible light. A: Guanine (G); B: 4-OHdG; C: G-; D: 8-OHdG; E: 8-oxodG.

We thank Dr. David M. Johnson of Ferrum College, VA, USA for his assistance in revising the draft manuscript. This work was supported by the National Natural Science Foundation of China (20877048, and 21177072), the National Basic Research Program of China (2008CB417206) and the Innovation Group Project of Hubei Province Natural Science Foundation (2009CDA020, and T200703).

1 Gates K S. An overview of chemical processes that damage cellular DNA: Spontaneous hydrolysis, alkylation, and reactions with radicals. Chem Res Toxicol, 2009, 22: 1747-1760

2 Menezo Y, Dale B, Cohen M. DNA damage and repair in human oocytes and embryos: A review. Zygote, 2010, 18: 357-365

3 Zhu R R, Wang S L, Chao J, et al. Bio-effects of nano- $\mathrm{TiO}_{2}$ on DNA and cellular ultrastructure with different polymorph and size. Mat Sci Eng C-Bio S, 2009, 29: 691-696

4 Huang Y P, Li J, Ma W H, et al. Efficient $\mathrm{H}_{2} \mathrm{O}_{2}$ oxidation of organic pollutants catalyzed by supported iron sulfophenylporphyrin under visible light irradiation. J Phys Chem B, 2004, 108: 7263-7270

$5 \mathrm{Lv}$ X J, Xu Y M, Lv K L, et al. Photo-assisted degradation of anionic and cationic dyes over iron(III)-loaded resin in the presence of hydrogen peroxide. J Photoch Photobio A, 2005, 173: 121-127

6 Beck J S, Vartuli J C, Roth W J, et al. A new family of mesoporous molecular sieves prepared with liquid crystal templates. J Am Chem Soc, 1992, 114: 10834-10843

7 Chen L, Zhou M. 8-Hydroxydeoxyguanosine, a marker of oxidative DNA damage, is increased in prostatic adenocarcinoma: Detection by HPLC-EC and immunohistochemistry. In: 14th Annual Meeting of the Association for Molecular Pathology. Texas: Grapevine, 2008. 606-607

8 Iwamoto T, Hiraku Y, Okuda M, et al. Mechanism of UVA-dependent DNA damage induced by an antitumor drug dacarbazine in relation to its photogenotoxicity. Pharm Res, 2008, 25: 598-604

9 Lin X J, Wang Q, Wu J, et al. DFT study on the mechanism of DNA damage caused by the isomerization of DNA purine base. J Theor Comput Chem, 2008, 7: 457-472

10 Huang Y P, Liu D F, Zhang S Y, et al. Fenton photocatalytic degradation of organic dye under visible irradiation (in Chinese). Chem J Chinese U, 2005, 26: 2273-2278

11 Fang Y F, Huang Y P, Luo G F, et al. Determination of hydrogen peroxide in painwater by fluorometry (in Chinese). Spectrosc Spect Anal, 2008, 28: 917-921

12 Jiang L R, Zhao C, Huang Y P, et al. Photocatalytic degradation of organic pollutants by $\alpha-\mathrm{FeOOH}$ under visible light (in Chinese). Environ Chem, 2007, 26: 434-438

13 Roszkowski K, Blaszczyk P. Oxidative DNA damage as a potential marker for radiotherapy. Wspolczesna Onkol, 2009, 13: 125-128

14 Brillas E, Sires I, Oturan M A. Electro-Fenton process and related electrochemical technologies based on Fenton's reaction chemistry. Chem Rev, 2009, 109: 6570-6631

15 Guo W, An Y, Jiang L P, et al. The protective effects of hydroxytyrosol against UVB-induced DNA damage in $\mathrm{HaCaT}$ cells. Phytother Res, 2010, 24: 352-359

16 Murakami K, Haneda M, Makino T, et al. Prooxidant action of furanone compounds: Implication of reactive oxygen species in the metal-dependent strand breaks and the formation of 8-hydroxy-2'deoxyguanosine in DNA. Food Chem Toxicol, 2007, 45: 1258-1262

17 Tsai C C, Wu S B, Cheng C Y, et al. Increased oxidative DNA damage, lipid peroxidation, and reactive oxygen species in cultured orbital fibroblasts from patients with Graves' ophthalmopathy: Evidence that oxidative stress has a role in this disorder. Eye, 2010, 24: 1520-1525

18 Al-Aubaidy H A, Jelinek H F. Hydroxy-2-deoxy-guanosine identifies oxidative DNA damage in a rural prediabetes cohort. Redox Rep, 2010, 5: 155-160

Open Access This article is distributed under the terms of the Creative Commons Attribution License which permits any use, distribution, and reproduction in any medium, provided the original author(s) and source are credited. 